\title{
SEROLOGICAL RESEARCH TOWARDS LYME BORRELIOSIS IN HUNTERS AND FORESTRY WORKERS IN SELECTED AREAS OF POLAND AND UKRAINE
}

\section{BADANIA SEROLOGICZNE W KIERUNKU BORELIOZY Z LYME WŚRÓD MYŚLIWYCH I PRACOWNIKÓW LEŚNICTWA W WYBRANYCH OBSZARACH POLSKI I UKRAINY}

\author{
Małgorzata Tokarska-Rodak ${ }^{1(\mathrm{~A}, \mathrm{~B}, \mathrm{C}, \mathrm{D}, \mathrm{E}, \mathrm{F})}$, Mariia Shkilna ${ }^{2(\mathrm{~A}, \mathrm{~B}, \mathrm{E}, \mathrm{F})}$, Dorota Plewik ${ }^{3(\mathrm{~B}, \mathrm{D})}$, \\ Anna Pańczuk ${ }^{4(B)}$, Mykhailo Korda ${ }^{2(B)}$, Ivan Klishch ${ }^{2(B)}$, Justyna Paszkiewicz ${ }^{1(B)}$, \\ Mykhailo Andreychyn ${ }^{2(B)}$
}
${ }^{1}$ Institute of Health Sciences, Pope John Paul II State School of Higher Education in Biala Podlaska, Poland
${ }^{2}$ I. Ya. Horbachevsky Ternopil State Medical University, Ukraine
${ }^{3}$ Innovation Research Centre, Pope John Paul II State School of Higher Education in Biala Podlaska, Poland
${ }^{4}$ Institute of Physical Education and Physiotherapy, Pope John Paul II State School of Higher Education
in Biala Podlaska, Poland

Authors' contribution Wkład autorów:

A. Study design/planning zaplanowanie badań

B. Data collection/entry zebranie danych

C. Data analysis/statistics dane - analiza i statystyki D. Data interpretation interpretacja danych E. Preparation of manuscript przygotowanie artykułu F. Literature analysis/search wyszukiwanie i analiza literatury G. Funds collection zebranie funduszy

\section{Summary}

Background. The study aimed to analyse the prevalence of antibodies to specific Borrelia burgdorferi antigens in hunters from the area of Lublin Province (Poland) and forestry workers from the vicinity of Ternopil (Ukraine).

Material and methods. The study group included 240 hunters, members of the hunting clubs in Lublin Province (Poland), aged 23-80 and 339 forestry workers employed in the 5 forest districts subordinated to the Ternopil Regional Administration of Forestry and Hunting, aged 18-76. All persons were given anti-B. burgdorferi IgM/IgG antibodies (ELISA test and Western blot).

Results. Positive anti- $B$. burgdorferi IgM/IgG results were found in $21.7 \%$ of the hunters and $31.9 \%$ of the forestry workers. The occurrence of positive results in anti-B. burgdorferi antibodies depends significantly $(\mathrm{p}<0.02)$ on the area of the tested persons from Ukraine and was higher in the Berezhany district $-48.2 \%$ and the Buchach district $-47.5 \%$.

Conclusions. Because of the high exposure to tick bites and the possibility of $B$. burgdorferi infection, it is justified and desirable to strive to implement a full two-step diagnostic approach to Lyme disease in forestry workers in Ukraine. Further, it is particularly vital to undertake extensive educational and diagnostic activities, especially in the Berezhany and Buchach districts. Finally, it would be beneficial to implement systemic solutions in this regard also in hunters due to the ever-increasing number of this professional group each year.

Keywords: foresters, hunters, Borrelia burgdorferi, Poland, Ukraine

\section{Streszczenie}

Cel pracy. Celem pracy była analiza częstości występowania przeciwciał dla specyficznych antygenów Borrelia burgdorferi wśród myśliwych z terenu woj. lubelskiego (Polska) i pracowników leśnict wa z okolic Tarnopola (Ukraina).

Materiał i metody. Grupa badana obejmowała: 240 myśliwych zrzeszonych w kołach łowieckich na terenie województwa lubelskiego (Polska) w wieku 23-80 oraz 339 pracowników leśnictwa zatrudnionych w 5 nadleśnictwach podległych The Ternopil Regional Administration of Forestry and Hunting w wieku 18-76. U wszystkich osób wykonano oznaczenia przeciwciał IgM/IgG anty-B. burgdorferi (test ELISA i Western blot).

Wyniki. Dodatnie wyniki IgM/IgG anty-B. burgdorferi stwierdzono u $21.7 \%$ myśliwych i $31.9 \%$ pracowników leśnictwa. Przeciwciała IgG częściej $(\mathrm{p}<0.0001)$ stwierdzano u leśników z Ukrainy. Występowanie wyników dodatnich $\mathrm{w}$ zakresie przeciwciał anty- $B$. burgdorferi zależy istotnie $(\mathrm{p}<0.02)$ od rejonu z którego pochodzili badani z Ukrainy i był wyższy w okręgu Berezhany $-48.2 \%$ i okręgu Buchach $-47.5 \%$.

Wnioski. Z racji na duże narażenie na pokłucia przez kleszcze i możliwość zakażenia $B$. burgdorferi uzasadnione i celowe jest dążenie do wdrożenia w Ukrainie obowiązku pełnej, dwuetapowej diagnostyki w kierunku boreliozy z Lyme u pracowników leśnictwa. Szczególnie ważne wydaje sie podjęcie szeroko zakrojonych działań edukacyjnych i diagnostycznych szczególnie w rejonach Berezhany i Buchach. Korzystne byłoby wdrożenie systemowych rozwiązań w tym zakresie również wśród myśliwych z racji na z roku na rok rosnącą liczbę osób zajmujących się łowiectwem.

Słowa kluczowe: leśnicy, myśliwi, Borrelia burgdorferi, Polska, Ukraina
Fibles: 3

References: 25

Submitted: 2017 Mar 28

Accepted: 2017 Apr 13

Tokarska-Rodak M, Shkilna M, Plewik D, Pańczuk A, Korda M, Klishch I, et al. Serological research towards Lyme borreliosis in hunters and forestry workers in some selected areas of Poland and Ukraine. Health Prob Civil. 2017; 11(4): 287-292. DOI: https://doi.org/10.5114/hpc.2017.69024

Address for correspondence / Adres korespondencyjny: Małgorzata Tokarska-Rodak, Institute of Health Sciences, Pope John Paul II State School of Higher Education, Sidorska 102, 21-500 Biała Podlaska, Poland, e-mail: rodak.malgorzata@gmail.com, phone +48 833449900

Copyright: (C) 2017 Pope John Paul II State School of Higher Education in Biała Podlaska, Małgorzata Tokarska-Rodak, Mariia Shkilna, Dorota Plewik, Anna Pańczuk, Mykhailo Korda, Ivan Klisch, Justyna Paszkiewicz, Mykhailo Andreychyn. This is an Open Access journal, all articles are distributed under the terms of the Creative Commons Attribution-NonCommercial-ShareAlike 4.0 International (CC BY-NC-SA 4.0) License (http://creativecommons.org/licenses/by-nc-sa/4.0/), allowing third parties to copy and redistribute the material in any medium or format and to remix, transform, and build upon the material, provided the original work is properly cited and states its license. 


\section{Introduction}

The primary vectors of Borrelia burgdorferi sensu lato spirochetes (B. burgdorferi s.l.) in Europe are larvae, nymphs and adult ticks Ixodes ricinus and Dermacentor reticulatus [1] feeding, depending on their developmental phase, mainly on various wildlife vertebrates [2]. The research did not show the relationship between $B$. burgdorferi s.l. and specific reservoir species [1]. The spirochetes are usually found in vertebrate organisms such as: small mammals (mice, goats, rabbits, rats, hamsters, rabbits, hedgehogs, squirrels, dormice, garden dormice), game (roe deer, deer, fallow deer), birds (blackbirds, trushes, guillemots, gulls, auks, wrens, pheasants, cormorants) as well as reptiles (lizards). Man is an incidental host for an infected nymph or adult tick [1,3,4,5].

The border area of Eastern Poland and Western Ukraine is similar in its natural surroundings. The area is characterised by mixed forests with rich lining, which provides a favourable habitat for ticks. The spread of infected ticks B. burgdorferi s.l. ranges from 6\% - 15\% in Poland and affects both rural and urban areas [1]. In western Ukraine, B. burgdorferi s.l spirochetes were identified in $14.2 \%-17.2 \%$ of the adult ticks Ixodes scapularis $[6,7]$. Other authors suggest that the incidence of tick infections may be as high as 25\% [8]. The Ternopil region, located in the western part of Ukraine, is an endemic area of Lyme disease. Habitats of the tick Ixodes ricinus were found in 57 settlements of the 15 districts in the vicinity of Ternopil [9].

Forestry workers, loggers and hunters working in these forest areas are prone to frequent tick bites and therefore ticks diseases, including Lyme borreliosis [10]. When that happens, the illness can significantly hinder or even prevent professional activity of the infected persons. Bacteria induce the degradation of extracellular matrix (ECM), activate enzymes (elastase, laminase), merge with fibronectin, integrins, proteoglycans (decorin), which as a result enables their survival in extracellular structures and generates diverse clinical manifestations of infection [11].

The study aimed to analyse the prevalence of antibodies for specific Borrelia burgdorferi antigens in hunters from the area of Lublin Province (Poland) and forestry workers from the vicinity of Ternopil (Ukraine). Because of their professional activity and hobbies, these persons are particularly prone to be bitten by ticks. The Polish hunters and the Ukrainian forestry workers (in contrast to the Polish foresters) are not covered by regular preventive and diagnostic measures that show be taken due to their exposure to B. burgdorferi.

\section{Material and methods}

\section{Study group}

The study group included:

- 240 hunters, members of the hunting clubs in Lublin Province (Poland), aged 23-80 (mean 52, SD 11.6), including 212 men (88.3\%) and 28 women (11.7\%);

- 339 forest workers employed in the 5 forest districts subordinated to the Ternopil Regional Administration of Forestry and Hunting: Berezhany (56), Ternopil (64), Chortkiv (65), Buchach (61), Kremenets (93) in the Ternopil region. The tested persons were aged 18-76 (mean 42, SD 11.2), including 337 men (99.4\%) and 2 women $(0.6 \%)$.

The blood samples were taken between 2014 and 2015.

\section{Serological tests}

In all persons, anti- $B$. burgdorferi IgM/IgG antibodies were marked using the ELISA test (anti-Borrelia ELISA IgM; anti-Borrelia plus VlsE ELISA IgG, Euroimmun, Germany) as the screening assay. The results obtained are interpreted following the manufacturer's instructions. The results above 22 relative units $/ \mathrm{ml}(\mathrm{RU} / \mathrm{ml}) \mathrm{were}$ interpreted as positive, below $16 \mathrm{RU} / \mathrm{ml}$ as negative, and those between $16-22 \mathrm{RU} / \mathrm{ml}$ as borderline.

The positive and borderline results obtained by the ELISA test were confirmed by Western blot (Wb) (antiBorrelia Euroline-WB IgM/IgG, Euroimmun, Germany). Test strips showed B. afzelii antigens (p83, p41, p39/ BmpA, p31/OspA, p30, p25/OspC, p21, p19, p17/DbpA) and a recombinant VlsE antigen. The test strips reading and the results interpretation were done following the manufacturer's instructions using the EuroLinescan software (Euroimmun, Germany).

The research was approved by the Bioethics Committee of the Medical University of Lublin (No. KE0254/177/2014) and Bioethics Committee of I. Ya. Horbachevsky Ternopil State Medical University (No 30, dated 01/09/2015).

The results of the study were then statistically analysed using the Statistica v. 10 programme. In all examined cases, the significance level $\mathrm{p}<0.05$ was assumed. 


\section{Results}

Positive anti-B. burgdorferi IgM results were found in $2.1 \%$ of the hunters and $1.5 \%$ of the forestry workers. The presence of both anti-B. burgdorferi IgM/IgG was detected in $0.4 \%$ of the hunters and $3 \%$ of the forestry workers. The number of anti- $B$. burgdorferi IgG was significantly higher in the Polish foresters $(\mathrm{p}<0.0001)$ (19.2\% of the hunters; $27.4 \%$ of the foresters). The detailed results are given in Table 1.

The occurrence of positive results with regard to anti- $B$. burgdorferi antibodies depended significantly $(\mathrm{p}<0.02)$ on the area of the tested persons from Ukraine and was higher in the Berezhany district $-48.2 \%$ and the Buchach district $-47.5 \%$. The detailed data are provided in Table 2.

The IgM and IgG antibodies for specific B. burgdorferi antigen proteins were detected by Western blot with different frequencies. The results are presented in Table 3.

IgG antibodies to some $B$. burgdorferi antigens were significantly more common in the Ukrainian forestry workers than in the Polish hunters: p21 (p<0.0004), p30 ( $<<0.00001), p 31(\mathrm{p}<0.05), \mathrm{p} 39(\mathrm{p}<0.00008)$, VlsE $(\mathrm{p}<0.0002)$.

The patients in the Berezhany district (Ukraine) were more likely $(\mathrm{p}<0.0004)$ than those in the other districts to have anti-p19 B. burgdorferi IgG antibodies (10 persons, 17.9\%), anti-p25 ( $\mathrm{p}<0.008,16$ persons, $28.6 \%)$, anti-p39 ( $\mathrm{p}<0.004,12$ persons, 21.4\%), anti-VlsE ( $\mathrm{p}<0.05)$ (18 persons, 32.1\%).

In the Buchach district (Ukraine), anti-p25 B. burgdorferi IgG was encountered more often $(\mathrm{p}<0.008)$ in 22 persons (36.0\%), anti-p39 ( $\mathrm{p}<0.004)$ in 17 persons $(27.9 \%)$, and anti-VlsE $\mathrm{p}<0.05$ in 26 persons $(42.6 \%)$.

Table 1. Anti-B. burgdorferi IgM/IgG antibodies in the tested hunters from Lublin Province (Poland) and the forestry workers from the vicinity of Ternopil (Ukraine)

\begin{tabular}{|c|c|c|c|c|c|c|c|c|}
\hline \multirow{2}{*}{$\begin{array}{l}\text { The tested } \\
\text { group }\end{array}$} & \multicolumn{7}{|c|}{ Anti-B. burgdorferi antibodies } & \multirow[b]{2}{*}{ Total } \\
\hline & $\begin{array}{l}\text { IgM- } \\
\text { IgG- }\end{array}$ & IgM+ & IgM+/- & $\begin{array}{l}\text { IgM+ } \\
\text { IgG+ }\end{array}$ & $\begin{array}{c}\text { IgM+/- } \\
\text { IgG+ }\end{array}$ & IgG+/- & IgG+ & \\
\hline $\begin{array}{l}\text { Hunters } \\
\text { (PL) }\end{array}$ & $163(67,9)$ & $5(2.1)$ & $5(2.1)$ & $1(0.4)$ & $2(0.8)$ & $18(7.5)$ & $46(19.2)$ & $240(100)$ \\
\hline $\begin{array}{c}\text { Forestry } \\
\text { workers } \\
\text { (UA) }\end{array}$ & $219(64.6)$ & $5(1.5)$ & $5(1.5)$ & $10(3.0)$ & $7(2.1)$ & - & $93(27.4)$ & $339(100)$ \\
\hline
\end{tabular}

PL - Poland UA - Ukraine

the value in brackets is given in percent (\%)

- a negative result

$-/+$ a borderline result

+ a positive result

Table 2. Anti-B. burgdorferi IgM/IgG antibodies in the forestry workers from Ukraine by the areas from which the tested persons came

\begin{tabular}{|c|c|c|c|c|c|c|c|c|}
\hline \multirow{2}{*}{$\begin{array}{c}\text { Forestry } \\
\text { workers } \\
\text { (UA) }\end{array}$} & \multicolumn{9}{|c|}{\begin{tabular}{c} 
Anti-B. burgdorferi antibodies \\
IgM- \\
\cline { 2 - 9 }
\end{tabular}} & IgG- & IgM+ & IgM+/- & $\begin{array}{c}\text { IgM+ } \\
\text { IgG+ }\end{array}$ & $\begin{array}{c}\text { IgM+/- } \\
\text { IgG+ }\end{array}$ & IgG+/- & IgG+ & \\
\hline 1 & $28(50.0)$ & $0(0)$ & $1(1.8)$ & $5(8.9)$ & $1(1.8)$ & - & $21(37.5)$ & $56(16.5)$ \\
\hline 2 & $44(68.7)$ & $2(3.1)$ & $1(1.6)$ & $0(0)$ & $1(1.6)$ & - & $16(25.0)$ & $64(18.9)$ \\
\hline 3 & $48(73.8)$ & $0(0)$ & $0(0)$ & $1(1.5)$ & $1(1.5)$ & - & $15(23.1)$ & $65(19.2)$ \\
\hline 4 & $31(50.8)$ & $1(1.6)$ & $1(1.6)$ & $3(4.9)$ & $0(0)$ & - & $25(41.0)$ & $61(18.0)$ \\
\hline 5 & $68(73.1)$ & $2(2.1)$ & $2(2.1)$ & $1(1.1)$ & $4(4.3)$ & - & $16(17.2)$ & $93(27.4)$ \\
\hline Overall & $219(64.6)$ & $5(1.5)$ & $5(1.5)$ & $10(3.0)$ & $7(2.1)$ & - & $93(27.4)$ & $339(100)$ \\
\hline
\end{tabular}

UA - Ukraine, 1-Berezhany, 2-Ternopil, 3-Chortkiv, 4-Buchach, 5- Kremenets

the value in brackets is given in percent (\%)

- a negative result

$-/+$ a borderline result

+ a positive result 
Table 3. IgM and IgG antibodies identified by Western blot for specific B. burgdorferi antigenic proteins in the group of hunters from Poland and forestry workers from Ukraine

\begin{tabular}{|c|c|c|c|c|c|c|c|c|c|c|}
\hline \multirow{2}{*}{$\begin{array}{l}\text { Antibody } \\
\text { class }\end{array}$} & \multirow{2}{*}{ Country } & \multicolumn{9}{|c|}{ B. burgdorferi antigenic proteins } \\
\hline & & p17 & p19 & p21 & p25 & p30 & p31 & p39 & p83 & VlsE \\
\hline \multirow{2}{*}{$\operatorname{IgM}$} & $\begin{array}{c}\text { PL } \\
\text { (hunters) }\end{array}$ & - & - & - & $\begin{array}{c}6 \\
(2.5)\end{array}$ & - & - & - & - & - \\
\hline & $\begin{array}{c}\text { UA } \\
\text { (forestry } \\
\text { workers) } \\
\end{array}$ & $\begin{array}{c}2 \\
(0.6)\end{array}$ & - & - & $\begin{array}{c}10 \\
(2.9)\end{array}$ & - & $\begin{array}{c}4 \\
(1.2)\end{array}$ & - & - & - \\
\hline \multirow{2}{*}{ IgG } & $\begin{array}{c}\text { PL } \\
\text { (hunters) }\end{array}$ & $\begin{array}{c}36 \\
(15.0)\end{array}$ & $\begin{array}{c}25 \\
(10.4)\end{array}$ & $\begin{array}{c}5 \\
(2.1)\end{array}$ & $\begin{array}{c}13 \\
(5.4)\end{array}$ & $\begin{array}{c}13 \\
(5.4)\end{array}$ & $\begin{array}{c}16 \\
(6.7)\end{array}$ & $\begin{array}{c}19 \\
(7.9)\end{array}$ & $\begin{array}{c}24 \\
(10.0)\end{array}$ & $\begin{array}{c}31 \\
(13.0)\end{array}$ \\
\hline & $\begin{array}{c}\text { UA } \\
\text { (forestry } \\
\text { workers) }\end{array}$ & $\begin{array}{c}52 \\
(15.3)\end{array}$ & $\begin{array}{c}26 \\
(7.7)\end{array}$ & $\begin{array}{c}34 \\
(10.0)\end{array}$ & $\begin{array}{c}22 \\
(6.5)\end{array}$ & $\begin{array}{c}67 \\
(19.8)\end{array}$ & $\begin{array}{c}44 \\
(13.0)\end{array}$ & $\begin{array}{c}62 \\
(18.3)\end{array}$ & $\begin{array}{c}48 \\
(14.2)\end{array}$ & $\begin{array}{c}93 \\
(27.4)\end{array}$ \\
\hline
\end{tabular}

PL - Poland, UA - Ukraine

the value in brackets is given in percent (\%)

\section{Discussion}

The ticks infestation in a given area can be estimated from the prevalence of $B$. burgdorferi antibodies in the blood of the residents or workers in a given region [12]. In European countries, anti-B. burgdorferi IgM/ IgG antibodies were reported in forestry workers (woodcutters, foresters, hunters) with different frequencies depending on the country and geographic region: in France 14.1 - 20.2\%; in Italy 5.4 - 23.2; in Germany 8 - 43\%; in the Netherlands 19.3\%; in Slovenia 23.8\%; in Romania 9.4\%; in Turkey 10.9; in Hungary 37\% [13] and in Austria $7 \%-42 \%$ [10]. In Poland, antibodies for specific antigens of B. burgdorferi s.l. were found in forestry workers with deferent frequencies depending on the region of the country: 32.7\% (in Kujawsko-Pomorskie Province) [14], 47.9\% [15] - 55\% (Lublin Province) [16], whereas in the area of Polesie and Forest-Steppe of Ukraine 30.4 - 50.0\% [17]. While forestry workers in Poland are well-monitored for the risk of B. burgdorferi infection and Lyme disease, there are no such procedures provided for this occupational group in Ukraine. There are also no uniform Lyme diagnostic recommendations. However, according to The Order of the Minister of Health of Ukraine, N133 of 19.07.1995, Lyme disease was classified into the group of particularly dangerous infections.

In the conducted two-stage studies (ELISA tests, Western blot), the anti-B. burgdorferi IgM/IgG antibodies were found in $31.9 \%$ of the forestry workers from the vicinity of Ternopil (Ukraine). The occurrence of positive anti-B. burgdorferi results depends significantly on the Ukrainian region from which the tested persons came. Higher positive results were in Berezhany district (48.2\%) and Buchach district (47.5\%).

The group of the Polish people who are not adequately protected against tick-borne diseases are hunters, who are mainly exposed to frequent tick-bites and the risk of Lyme borreliosis when undertaking activities related to hunting and wildlife conservation. In the conducted studies, the anti B. burgdorferi IgM/IgG were present in $21.7 \%$ of the hunters from Lublin Province (Poland). The results show that seroprevalence in this group is significantly higher than in those who are not exposed to ticks $(7.1 \%-12.5 \%$ of the blood donors $)[13,18]$, and similar to that obtained for farmers from Lublin Province (27.3\% [19], and 28\% [16]) of those professionally exposed to Lyme disease. The obtained data indicate that these particular groups of people from both countries should be provided with meticulous care for the diagnosis and prevention of Lyme disease.

The diagnosis of Lyme borreliosis is based on three criteria: the individual's ticks bite history, clinical manifestations of the disease and serological tests (ELISA tests and Western blot) indicating the presence of the specific anti-B. burgdorferi IgM/IgG antibodies [20]. While evaluating and interpreting the results of the serological tests, both the antibody class for the specific B. burgdorferi antigenic proteins and the type of bacterial antigen for which these antibodies are produced are significant. Outer surface proteins (Osp) play an important role in the immune response to the infection because they are highly immunogenic, and anti-OspC (p25), OspA (p31), and OspB antibodies can destroy B. burgdorferi spirochetes [21].

The EUCALB (European Union Concerted Action on Lyme Borreliosis) programme demonstrated that the following B. burgdorferi s.l. antigenic proteins: OspC and p41 for IgM and p83/100, p58, p41, p39, OspC, DbpA (p17) are useful in Western blot testing for IgG. It is essential that the diagnostic criteria take into account the immune response to the antigens of the most common strains in the area. In Europe, it is Western blot tests with B. afzelii antigens (the PKo strain) that are recommended [22]. In these tests, recombinant B. burgdorferi 
antigens are most useful: p100, p58, p41i, VlsE, OspC, DbpA [23]. The diagnostic significance of OspC decreases with the progress of the immune response and an increased production of IgG antibodies to other spirochete antigen proteins $[24,25]$.

In forest workers, B. burgdorferi anti-DbpA IgG (65\%) and anti-OspC (35\%) were identified [16]. The studies have confirmed the diagnostic role of p17 (DbpA), p19, p25, p39, VlsE antigens in the assessment of late manifestation of B. burgdorferi infection.

\section{Conclusions}

Because of the high exposure to tick bites and the possibility of B. burgdorferi infection, it is justified and desirable to strive for the implementation of a full two-step diagnostic approach to Lyme disease in forestry workers in Ukraine. It is particularly vital to undertake wide-ranging educational and diagnostic activities among Ukrainian foresters, especially in the Berezhany and Buchach districts. Further, it would also be beneficial to implement systemic solutions for hunters in this area due to the ever-increasing number of this professional group each year.

\section{References:}

1. Tylewska-Wierzbanowska S, Chmielewski T. Zoonozy przenoszone przez kleszcze. Post Mikrobiol. 2010; 49, 3: 191-197.

2. Adamek B, Książek A, Szczerba-Sachs A, Kasperczyk J, Wiczkowski A. Narażenie pracowników leśnych na choroby odkleszczowe a stosowane metody prewencji. Przegl Epidemiolog. 2006; 60: 11-15.

3. Hubalem Z, Halouzka J. Distribution of Borrelia burgdorferi sensu lato genome groups in Europe, a review. Eur J Epidemiol. 1997; 13, 8: 951-957.

4. Krajczy P, Skerka Ch, Kirschfink M, Zipfel PF, Brade V. Mechanism of complement resistance of pathogenic Borrelia burgdorferi isolates. Int Immunopharmacol 2001; 1: 393-401.

5. Movila A, Toderas I, Dubinina HV, Uspenskaia I, Alekseev AA. Zoonotic peculiarities of Borrelia burgdorferi s.l.: vector competence and vertebrate host specificity. In: A. Karami, editor. Lyme disease. INTECH; 2012. p. 1-26.

6. Semenyshyn OB. The ecologic and epidemiologic characteristic of ixodal tick-borne borreliosis in west Ukrainian region - thesis of dissertation on obtaining of a scientific degree of the candidate of medical sciences on a speciality 14.02.02 - epidemiology. State establishment "Lev Gromashevsky Institute of Epidemiology and Infectious diseases of Academy of Medical Sciences of Ukraine", Kyiv, 2009.

7. Luhovskoy E, Fesenko I. Prevention of Lyme disease and algorithm of actions at the tick bite. [cited: 2017 March 25]. Available from: http://www.ses.lviv.ua/seslab/index.php?id=219 (2008)

8. Biletska G, Podavalenko A, Semenyshyn A, Lozinski I. Ecological and epidemiological aspects of the spread of Lyme disease in Ukraine. Problems of medical science and education 2007; 4: 12-14.

9. Shkilna M. Lyme borreliosis in forestry workers of Ternopil region. Infectious diseases 2016; 1(83): 36-40.

10. Deutz A, Fuchs K, Nowotny N, Auer H, Schuller W, Stünzner D, et al. Sero-epidemiological studies of zoonotic infections in hunters - comparative analysis with veterinarians, farmers, and abattoir workers. Wien Klin Wochenschr. 2003;115 Suppl 3: 61-7. http://www.ncbi.nlm.nih.gov/pubmed/15508783

11. Zajkowska JM. Transmisja i krążenie patogenów odkleszczowych (KZM I boreliozy) i rola zmieniającego się środowiska. Przegl Epidemiol. 2010; 64: 525-531.

12. Wójcik-Fatla A, Szymańska J, Buczek A. Diseases transmitted by ticks. Pathogens Borrelia burgdorferi, Anaplasma phagocytophilum, Babesia microti. Public Heath. 2009; 119(2): 217-222.

13. Richard S, Oppliger A. Zoonotic occupational diseases in forestry workers - Lyme borreliosis, tularemia and leptospirosis in Europe. Ann Agric Environ Med. 2015; 22, 1: 43-50.

14. Dybowska D, Kozielewicz D, Abdulgater A. Rozpowszechnienie boreliozy wśród pracowników lasów województwa kujawsko-pomorskiego. Przegl Epidemiol. 2007: 61, 67-71.

15. Chmielewska-Badora J, Moniuszko A, Żukiewicz-Sobczak W, Zwoliński J, Piątek J, Pancewicz S. Serological survey in persons occupationally expose to tick-borne pathogens in casus of co-infections with Borrelia burgdorferi, Anaplasma phagocytophilum, Bartonella spp. and Babesia microti. Ann Agric Environ Med. 2012; 19(2): 271-274.

16. Tokarska-Rodak M. Plewik D, Kozioł-Montewka M, Szepeluk A, Paszkiewicz J. Ryzyko zakażeń zawodowych Borrelia burgdorferi u pracowników leśnictwa i rolników. Med Pr. 2014; 65(1): 109-117.

17. Zinchuk O. Asymtomatic Lyme borreliosis in workers occupational groups with a high risk of infection. Infectious diseases. 2014; 2(76): 39-42. 
18. Zwoliński J, Chmielewska-Badora J, Cisak E, Buczek A, Dutkiewicz J. Występowanie przeciwciał przeciw Anaplasma phagocytophilum i Borrelia burgdorferi u leśników w regionie lubelskim. Wiad Parazytol. 2004; 50(2): 221-227.

19. Cisak E, Chmielewska-Badora J, Zwoliński J, Dutkiewicz J, Patorska-Mach E. Ocena częstości zakażeń wirusem kleszczowego zapalenia mózgu i krętkami Borrelia burgdorferi wśród rolników indywidualnych na terenie Lubelszczyzny. Med Pr. 2003; 54(2): 139-144.

20. Stanek G, Fingerle V, Hunfeld KP, Jaulhac B, Kaiser R, Krause A, et al. Lyme borreliosis: Clinical case definitions for diagnosis and management in Europe. Clin Microbiol Infect. 2011 Jan; 17(1):69-79. doi: 10.1111/j.1469-0691.2010.03175.x.

21. Aguero-Rosenfeld ME,Wang G, Schwarz I, Womser GP. Diagnosis of Lyme borreliosis. Clin Microbiol Rev. 2005; 18, 3: 484-509.

22. Chmielewski T, Dunaj J, Gołąb E, Gut W, Orban A, Pancewicz S, et al. Diagnostyka laboratoryjna chorób odkleszczowych. Rekomendacje grupy roboczej [cited 2017 Feb 21]. Available from: http://kidl.org.pl/ uploads/rekomendacje/05_kleszcze\%20z\%20okladka.pdf

23. Pancewicz SA, Garlicki AM, Moniuszko-Malinowska A, Zajkowska J, Kondrusik M, Grygorczu S, et al. Diagnostyka i leczenie chorób przenoszonych przez kleszcze rekomendacje polskiego towarzystwa epidemiologów i lekarzy chorób zakaźnych. Przegl Epidemiol. 2015; 69: 421-428.

24. Aberer E. Lyme borreliosis-an update. Journal der Deutschen Dermatologischen Gesellschsft. 2007; 5(5): 406-413.

25. Hofmann H, Wallach R, Lorenz I. Comparison of a New line assai using purified and recombinant antigens with a European lysate blot for serodiagnosis of Lyme borreliosis. IJMM. 2006; 296: 288-290. 